\title{
Microbiostratigraphy of the Sediments of Talezang Formation in Ghalebi Section (Southwest Lorestan, Iran)
}

\author{
Mostafa Yousefi Rad, Hamideh Noroozpour \\ Faculty of Science, Department of Geology, Payame Noor University, Tehran, Iran \\ Email: Radyousefi@yahoo.com
}

Received 10 April 2015; accepted 9 June 2015; published 12 June 2015

Copyright (C) 2015 by authors and Scientific Research Publishing Inc.

This work is licensed under the Creative Commons Attribution International License (CC BY). http://creativecommons.org/licenses/by/4.0/

(c) (7) Open Access

\begin{abstract}
In the present paper, Talezang Formation, located in southwest of Khoramabad, is studied. Ghalebi section (200 $\mathrm{m}$ thickness) contains gray limestones with cherty nodules and sandy limestone isoclinally overlies Amiran Formation (gray shale and limestone). It is underlain concordantly and discontinuously by Kashkan Formation. 160 samples are surveyed (examined) from the section; 28 genera and 4 species of benthonic foraminifera and 6 genera and 2 species of algae are identified. Due to similarity between identified benthonic foraminifera and Miscellanea-Kathina Assemblage Zone, the age of Talezang Formation can be assumed late Paleocene (Thanetian).
\end{abstract}

\section{Keywords}

Biozone, Microbiostratigraphy, Paleocene, Talezang, Thanetian

\section{Introduction}

Talezang Formation with the age of late Paleocene-middle Eocene consists of rocky and massive limestone with varied thickness. Talezang Formation has mostly developed in northeast and center of Lorestan Province. It is normally located over Amiran Formation and under Kashkan Formation. This formation is replaced laterally by Amiran and Kashkan formations.

In addition, Talezang Formation has lateral connection with Pabdeh Formation, so there are often some fingers (tongues) of Talezang Formation inside Pabdeh Formation called Calcareous member of Talezang. In eastern parts of Lorestan Basin, Talezang Formation has greater thickness and a wider range. Therefore, based on former studies, type section and Kyalo section are extended to middle Eocene.

However, carbonated deposits of Talezang Formation, located in western parts of Lorestan Basin, are rarely 
situated in late Paleocene-early Eocene [1]-[6]. Ghalebi section (north of Ghalebi village) is situated in Tang-eTir area (Figure 1), with the geographic coordination of $47^{\circ} 55^{\prime} 32^{\prime \prime} \mathrm{E}-47^{\circ} 56^{\prime} 41^{\prime \prime} \mathrm{E}$ and $33^{\circ} 26^{\prime} 13^{\prime \prime} \mathrm{N}-33^{\circ} 27^{\prime} 11^{\prime \prime} \mathrm{N}$, in southwest of Khoramabad, structural zone of Zagros [7]. In this study, it is intended to approach to 2 following aims:

- Lithostratigraphy of Talezang Formation in the studied section.

- Micro-biostratigraphy of Talezang Formation by studying foraminiferal microfossils criteria that follows.

\section{Study Approach}

This research is based on field and laboratory studies. In the field studies, systematic sampling was completed in nearly $1.25 \mathrm{~m}$ intervals. 160 samples were surveyed to provide microscopic thin section and to study micro-biostratigraphic sequences. Some atlas and researches have been used to micro-fauna studies [1] [2] [5]-[15].

\subsection{Lithostratigraphic Description of Talezang Formation in the Studied Section}

Talezang deposits in Ghalebi section (200 m thickness) were measured. Dip and strike of sequences were averagely surveyed: $\mathrm{N} 120^{\circ} \mathrm{W} / 50 \mathrm{SW}$. In this section, limestones concordantly overlaid the dark marls and sandstones related to Amiran Formation. Carbonate and calcareous deposits of the end member were concordantly underlain by red massive conglomerates of Kashkan clastic formation (Figure 2).

Amiran Formation in the lower boundary consists of altered shale, gray marls, siltstones, olive green sandstones, chert and nodule fragments. Also, there are secondary sedimentary structures in this formation such as concretion, load cast and vermiculate.

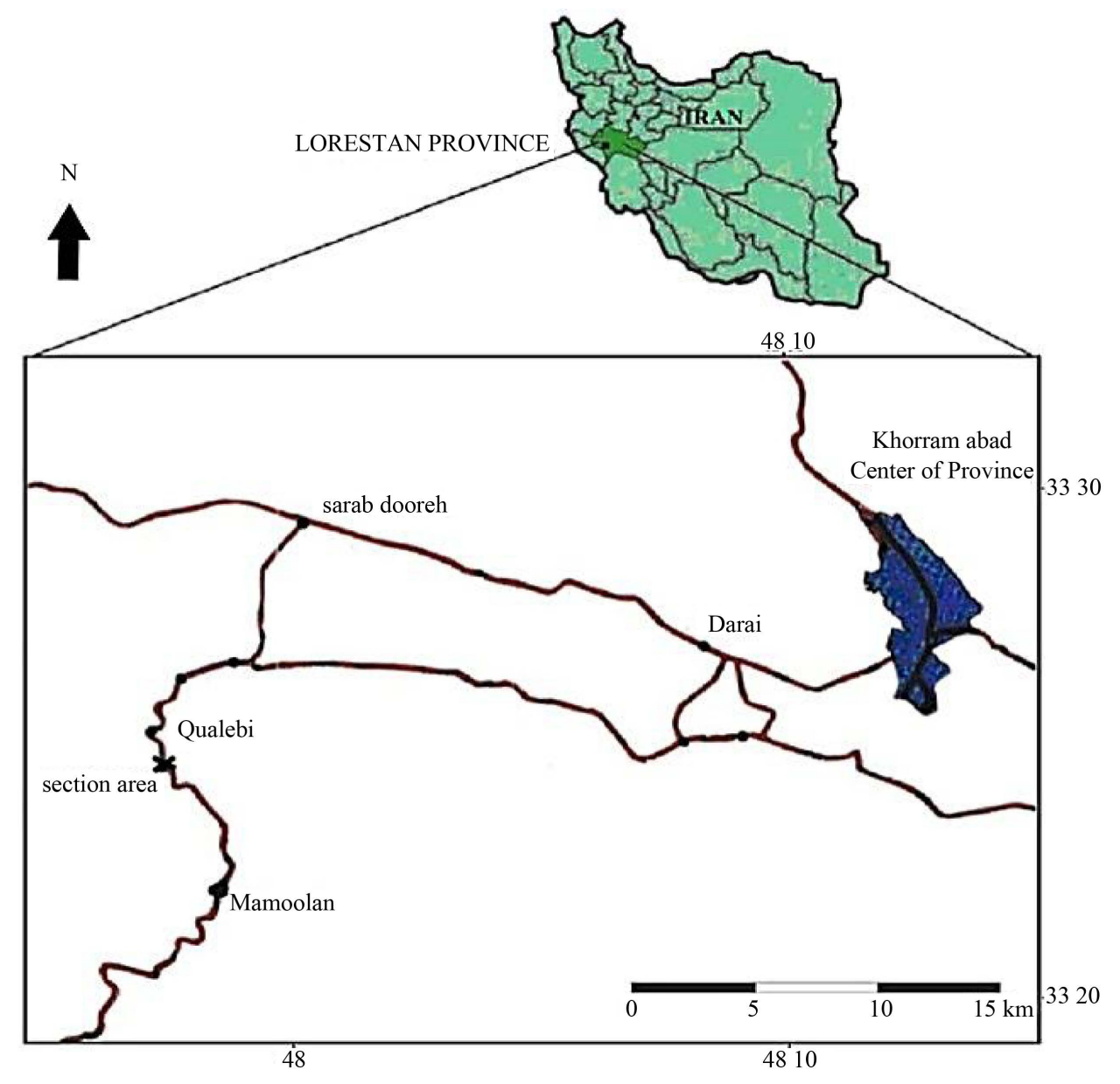

Figure 1. The studied section can be viewed from Khoramabab to Poledokhtar. 


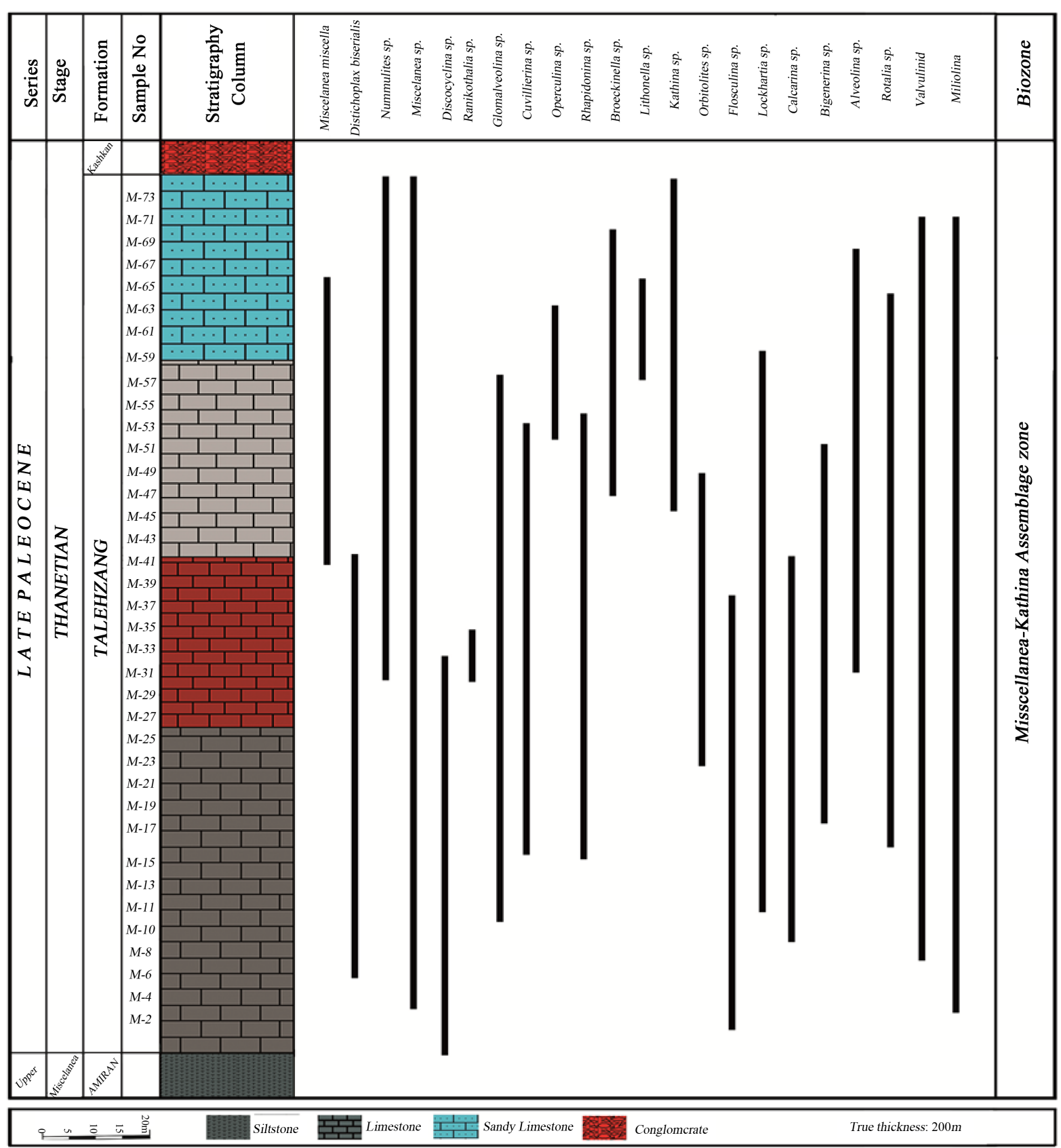

Figure 2. Stratigraphic and biozonation column of taleh zang formation in the tale-tir area.

Based on lithological studies and field evidences, Talezang Formation in the studied section generally includes one member that is composed of carbonate rocks as follows:

- $25.4 \mathrm{~m}$ alternation of light to dark limestone, thick-layered with load cast.

- 19.9 m altered medium to thick-layered limestone (gray to dark gray) with trace fossils.

- 33 m very thick-layered nodular to massive limestone (dark gray).

- 18.1 m thick to very thick layered sandy limestone (gray) with cherty and nodular concretions.

- 19.39m alternated massive and nodular limestone light to dark gray.

- 15.18 m thick-layered sandy limestone red to brown with fossiliferous cherty nodules.

- 13.5 m medium layered nodular sandy limestone (gray) with cherty cobbles in upper part.

- 28.5 m thick-layered sandy limestone (brown to red). 
In upper boundary with Kashkan Formation, there is a red to purple layer as a key bed. It is index to determine stratigraphic status of this formation. This rock unit is characterized by its red color and clastic facies including silt, sandstone and conglomerate with radiolaratic cobbles especially chert becoming coarser upwards.

\subsection{Biostratigraphy}

In Ghalebi section of Talezang Formation, fossils especially foraminifera and algae are very abundant in calcareous facies. Some species in studied section are as follows:

Miscellanea miscella, Rotelia (aff.Rotaliaprovalis), Cibicideslobatus, Distichoplaxbiserialis, Kathina sp., Textularides sp., Alveolinasp. (Glomalveolina), Elphidium sp., Miniacina sp., Lagenides sp., Glomospirella sp., Acicularia sp., Salpingoporella sp. and Gymnocodium sp.

It is necessary to note that there are diverse macrofauna associated with mentioned microfauna:

Serpula sp., worm tube, corals, ostracoda, bryozoa, echinoid spines, gastropoda and crinoid stem.

In Ghalebi section of Talezang Formation, fossils especially foraminifera and algae are very abundant in calcareous facies. Some species in studied section are as follows:

Miscellanea miscella, Rotelia (aff.Rotaliaprovalis), Cibicideslobatus, Distichoplaxbiserialis, Kathina sp., Textularides sp., Alveolinasp. (Glomalveolina), Elphidium sp., Miniacina sp., Lagenides sp., Glomospirella sp., Acicularia sp., Salpingoporella sp. and Gymnocodium sp.

It is necessary to note that there are diverse macrofauna associated with mentioned microfauna:

Serpula sp., worm tube, corals, ostracoda, bryozoa, echinoid spines, gastropoda and crinoid stem. indicate that the age of Talezang Formation is attributed to late Paleocene-middle Eocene in type section, but in the studied section, index species younger than Thanetian stage have not been identified.

Unlike the type section containing considerable variety of planktonic foraminifera, the studied section includes abundant various benthic foraminifera and planktonic species are rare.

\section{Conclusions}

By studying Talezang deposits in Ghalebi section, the following results are obtained:

1) Talezang calcareous deposits are 200 meter thick in the studied section.

2) Lower boundary of Talezang Formation in the studied section (southwestern of Lorestan) concordantly overlies Amiran Formation that is composed of marls, shale and olive green sandstones.

3) Upper boundary of the Talezang Formation is conformably covered by Kashkan Formation. In the studied section, Talezang Formation includes conglomerates and red siltstones that transitioned to limestone, sandy limestone and then Kashkan Formation which begins with sandstones and siltstones and ends by purple conglomerates considered as a key bed.

4) Among 160 samples from Ghalebi section, 28 genera and 4 species of red Algae and 1 biozone are identified.

5) Sequences of Talezang Formation contain benthic foraminifera. Thus, most of the occurred microfossils are benthic, and planktonic microfossils are very rare.

6) Based on available paleontological evidences and Miscellanea-Katina Assemblage Zone [7], age of the Talezang Formation is considered as Thanetian which indicates different age of Talezang Formation in many parts of the Lorestan basin.

According to paleontological records, several benthic foraminifera have been introduced in type section which have not occurred in Ghalebi section in southwest of Lorestan Province.

\section{References}

[1] Kalantary, A. (1969) Microbiostratigraphy of the Cretaceous-Lower Eocene Sucession Khoramabad-Kermanshah Area (W. Iran). The Iranian Petroleum Insitutue, Bulten, 1-24.

[2] Kalantary, A. (1979) Microbiostratigraphy of the Sarvestan Area, Southeastern Iran. N.I.O.C, Geological Laboratories, Publication No. 5, 129 p.

[3] James, G.A. and Wynd, J.G. (1965) Stratigraphic Nomenclature of Iranian Oil Consortium Agreement Area. A.A.P.G. Bulletin, 49, 2218-2232.

[4] Wynd, J.G. (1965) Biofacies of the Iranian Oil Consortium Agreement Area. N.I.O.C Report No.1082, 57-66. 
[5] Rahaghi, A. (1978) Paleogene Biostratigraphy of Some Parts of Iran. N.I.O.C Publication No.7.

[6] Rahaghi, A. (1983) Stratigraphy and Faunal Assemblage of Paleocene-Lower Eocene in Iran. N.I.O.C Publication No.10.

[7] Berberian, M. and King, G.C. (1981) Towards a Palaeogeography and Tectonics Evolution of Iran. Canadian Journal of Earth Sciences, 18, 210-265. http://dx.doi.org/10.1139/e81-019

[8] Alvarez, L.W., Alvarez, W., Asaro, F. and Michel, H.V. (1980) Extraterrestrial Cause for the Cretaceous-Tertiary Extinction. Science, 208, 1095-1108. http://dx.doi.org/10.1126/science.208.4448.1095

[9] Bandy, O.L. (1964) Cenozoic Planktonic Foraminifera Zonation. Micropaleontology, 10, 1-17. http://dx.doi.org/10.2307/1484621

[10] Berger, W.H. (1970) Planktonic Foraminifera: Selective Solution and the Lysocline. Marine Geology, 8, 111-138. http://dx.doi.org/10.1016/0025-3227(70)90001-0

[11] Berggren, W.A. (1970) Paleogene Planktonic Foraminiferal Faunas on Legs I-IV (Atlantic Ocean), Joides Deep Sea Drilling Program-A Synthesis. Proceedings of the II Planktonic Conference, Roma, 57-77.

[12] BouDagher-Fadel, M.K. (2008) Evolution and Geological Significance of Larger Benthic-Foraminifera, Developments in Palaeontology and Stratigraphy. Vol. 21, Elsevier, Amsterdam, 544.

[13] Henson, F.R.S. (1948) Larger Imperforate Foraminifera of South-Western Asia. British Museum (Natural History), $127 \mathrm{p}$.

[14] Racey, A. (1994) Biostratigraphy and Palaeobiogeographic Significance of Tertiary Nummulitids (Foraminifera) from Northern Oman. In: Simmons, M.D., Ed., Micropalaeontology and Hydrocarbon Exploration in the Middle East, Chapman \& Hall, London, 343-367.

[15] Bolli, H.M. and Krasheninnikov, V.A. (1977) Problems in Paleogene and Neogene Correlation Based on Planktonic Foraminifera. Micropalaeontology, 23, 436-452. 
All Samples: 100X

\section{Plate Explanation I}

Plate. 1\&2: Miscellanea miscella, Sample. No: P.R:16, 24.

Plate. 3: Rotalia (aff Rotaliaprovalis), Sample. No: P.R:5.

Plate. 4: Cibicides gr lobatus, Sample. No: P.R:8.

Plate. 5: Distichoplaxbiserialis, Sample. No: P.R:35.

Plate. 6: Kathina sp., Sample. No: P.R:41.

Plate. 7: Textularides sp., Sample. No: P.R:38.

Plate. 8: Alveolina (Glomalveolina). Sample. No: P.R:51.

Plate. 9: Elphidium sp., Sample. No: P.R:11.

Plate. 10: Miniacina sp., Sample. No: P.R:42.

Plate. 11: Lagenides sp., Sample. No: P.R:34.

Plate. 12: Glomospirella sp., Sample. No: P.R:27.

Plate. 13: Acicularia sp., Sample. No: P.R:18.

Plate. 14: Salpingoporella sp., Sample. No: P.R:22.

Plate. 15: Gymnocodium sp., Sample. No: P.R:45.
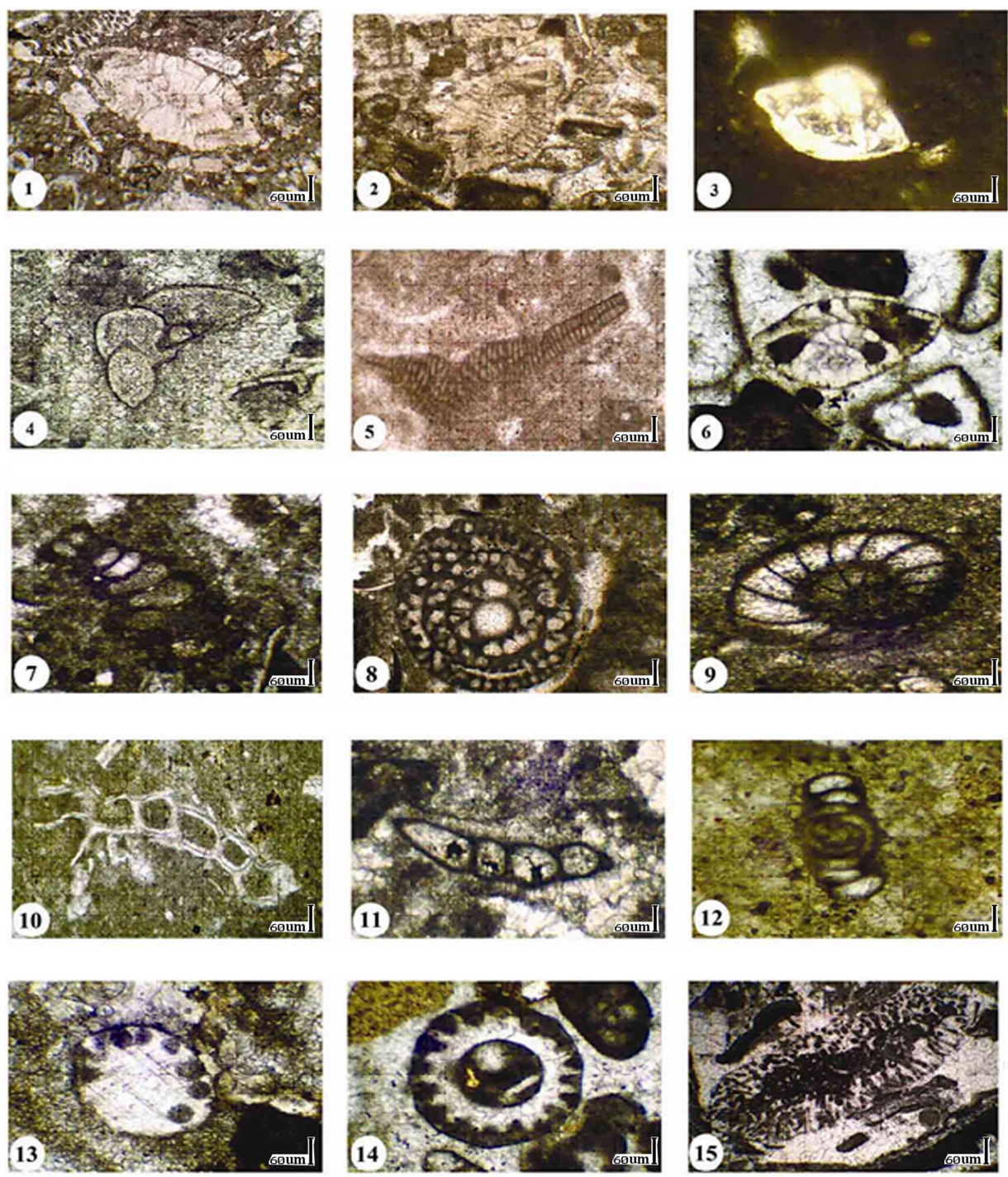